\title{
Cattle loading rates in different truck models and their relationship with bruises on bovine carcasses
}

\author{
Kethylleen de Carvalho Ferreira ${ }^{1}$ Aline Correia Furtado ${ }^{1}$ (D) Hugo Pereira Flores ${ }^{1}$ (D) \\ Pollyanna Ricartes de Oliveira de Oliveira ${ }^{1}$ (D) Augusto Galhardo Gonçalves ${ }^{1}$ (D) \\ Dalton Mendes de Oliveira ${ }^{1,2^{*}}$ (D)
}

${ }^{1}$ Universidade Estadual de Mato Grosso do Sul (UEMS), Unidade Universitária de Aquidauana, Aquidauana, MS, Brasil.

${ }^{2}$ Programa de Pós-graduação em Zootecnia, Universidade Estadual de Mato Grosso do Sul (UEMS), 79200-000, Aquidauana, MS, Brasil. E-mail: dmo@uems.br. "Corresponding author.

ABSTRACT: This study sought to evaluate the number of bruises on bovine carcasses and their relationship with loading rates in different truck models. Bruising percentages in the hindquarter, forequarter and short rib regions were evaluated. The space occupied on the truck by each animal in $m^{2}$ was defined as the Practiced area, obtained by dividing the body area by the number of males and females transported in straight trucks $(10.60 \times 2.40 \mathrm{~m})$ and livestock trailers $(14.80 \times 2.60 \mathrm{~m}), 240$ and 168 , and 120 and 93 , respectively, and 80 males in a straight truck with trailer configuration $(17.50 \times 2.60 \mathrm{~m})$. The minimum area occupied by the animals was assessed according to the Farm Animal Welfare Council (FAWC) and Animal Welfare Advisory Committee (AWAC). The data was analyzed in a completely randomized design and included two sex classes, three carcass regions and three truck types. For males, the minimum areas $\left(\mathrm{m}^{2}\right)$ calculated by the FAWC and AWAC were smaller (1.37 and $1.29 \mathrm{~m}^{2}$, respectively) for the straight truck. The straight truck with trailer configuration had the lowest (P=0.0025) bruising index in the forequarter region (15.1\%) and the highest $(P=0.047)$ in the short rib region (30.5\%). Females transported in the livestock trailer had a higher $(P<0.001)$ percentage of bruises in the forequarter region $(51.7 \%)$. There was a relationship between the high bruising rates and the loading rate Practiced for the males. Estimations made by the AWAC are close to those practiced in the upper Pantanal region of Mato Grosso do Sul, Brazil.

Key words: animal welfare, loading density, pre-slaughter handling, road transport.

Taxa de lotação em diferentes modelos de carrocerias e sua relação com hematomas em carcaças bovinas

\begin{abstract}
RESUMO: Este estudo teve por objetivo avaliar o número de hematomas em carcaças de bovinos e suas relações com as taxas de lotação em diferentes modelos de carrocerias. Foi avaliada a porcentagem de hematomas na região do traseiro, dianteiro e ponta da agulha (PA). $O$ espaço ocupado por cada animal em $\mathrm{m}^{2}$ foi definido como área Praticada, sendo obtido pela divisão da área da carroceria pelo número de machos e fêmeas transportados nos caminhões truck $(10,60 \times 2,40 \mathrm{~m})$ e carreta baixa $(14,80 \times 2,60 \mathrm{~m}) ; 240$ e $168 ; 120$ e 93 , respectivamente, e 80 machos em caminhão romeu e julieta $(17,50 \times 2,60 \mathrm{~m})$. Avaliou-se a área mínima ocupada por animal pela Farm Animal Welfare Council (FAWC) e Animal Welfare Advisory Committee (AWAC). Os dados foram analisados em um delineamento inteiramente casualizado sendo duas classes sexuais, três regiões da carcaça e três tipos de caminhões. Para machos, as áreas mínimas $\left(\mathrm{m}^{2}\right)$ pela FAWC e AWAC foram menores $\left(1,37\right.$ e 1,29 $\mathrm{m}^{2}$, respectivamente) para o caminhão truck. O caminhão romeu e julieta apresentou o menor $(P=0,0025)$ indice de hematomas na região dianteiro $(15,1 \%)$ e o maior $(P=0,047)$ na $P A(30,5 \%)$. As fêmeas transportadas no caminhão carreta baixa, apresentaram maior $(P<0,001)$ porcentagem de hematomas na região dianteiro $(51,7 \%)$. Houve relação entre os altos índices de hematomas e a taxa de lotação Praticada para o caminhão carreta baixa e romeu e julieta para machos. As determinações realizadas pela AWAC estão próximas das Praticadas no Alto Pantanal sul-mato-grossense.

Palavras-chave: bem-estar, densidade de carga, manejo pré-abate, transporte rodoviário.
\end{abstract}

\section{INTRODUCTION}

Demands for high-quality meat are constantly increasing, extending to both the international and national markets. However, the generation of high-quality meat products involves several segments of the agro-industrial chain, from cattle breeding to preparation for the final consumption of fresh meat and processed meat products. Problems related to meat quality have; therefore, been linked to animal welfare, especially pre-slaughter management with an emphasis on the cattle transport phase, which 
leads to an increase in carcass bruising, physiological stress and yield loss (DINIZ et al., 2011).

According to HOFFMAN et al. (1998), bruises can be defined as injuries occurring in muscle tissues usually caused by impacts with enough force to rupture blood vessels, resulting in the accumulation of blood in the tissues which makes it unsuitable for sale. Therefore, in addition to ethical principles, i.e., transport conditions within the well-being norms, carcass bruises are identified as one of the main causes for economic losses in slaughterhouses (ASSIS et al., 2011).

In Brazil, trucks or trailers are the main methods used to transport beef cattle destined for slaughter. However, transport becomes a cause of stress when animals are exposed to adversities such as inadequate loading rates and mixing of lots with differences in age and sex (ADZITEY, 2011; ROMERO et al., 2013; NUNES et al., 2018).

In general, of the factors specifically associated with transport, the space occupied by the animals or loading rate can be classified as high $\left(600 \mathrm{~kg} / \mathrm{m}^{2}\right)$, medium $\left(400 \mathrm{~kg} / \mathrm{m}^{2}\right)$ or low $(200$ $\mathrm{kg} / \mathrm{m}^{2}$ ) (TARRANT et al., 1988). Inappropriate loading densities (high or low) are factors that cause increased bruising and stress, and reduce meat quality (WARRISS, 1990; GONZÁLEZ et al., 2012). It should also be noted that, from an economical point of view, it is sought to transport animals with a high loading density (TARRANT et al., 1992). In Brazil, the average load density used is 390 to $410 \mathrm{~kg} / \mathrm{m}^{2}$ (ROÇA, 2001), with no difference between truck classes or animal sex.

Therefore, the objective of this study was to evaluate the number of bruises in cattle carcasses of different sex classes and its relationship with loading rates in different truck models used to transport animals to slaughter, in the southern upper Pantanal region of Mato Grosso do Sul, Brazil.

\section{MATERIALS AND METHODS}

This study was conducted in the municipality of Aquidauana, located in the Upper Pantanal region of the Brazilian state of Mato Grosso do Sul, at a slaughterhouse subject to federal inspection. Data was collected from animal carcasses transported in straight trucks, livestock trailers, and straight truck with trailer configurations. Bruise detection was performed in the slaughter line immediately after the skinning stage.

The percentage of carcasses affected by bruises was measured by region, dividing the body into hindquarter, short ribs, forequarter. A bruise was characterized by any accumulation of blood in the tissue caused by trauma. Bruising indices were characterized by taking into account the frequency of trauma occurring in the following quantities 0,1 to 5 , 6 to 10,11 to 15 and $>15$, expressed in percentage.

In addition, the color of the bruise was considered. Those presenting a reddish color were characterized as newer (less than one day), according to the subjective and visual determination colorimetric scale proposed by ANDRADE et al. (2009), since the intention was to evaluate bruises resulting from land transport, so those of different coloration were not considered.

The space occupied on the truck by each animal in $\mathrm{m}^{2}$ during transportation in the region was defined as the Practiced area, obtained by dividing the body area by the number (no.) of animals (male or female) transported, being $25.44 \mathrm{~m}^{2} / \mathrm{no}$. for the straight truck, $38.48 \mathrm{~m}^{2} /$ no. for the livestock trailer and $45.50 \mathrm{~m}^{2} / \mathrm{n}^{\circ}$ for the straight truck with trailer. In order to obtain $\mathrm{kg} / \mathrm{m}^{2}$, the average live weight $(\mathrm{kg})$ was divided by the occupied area in $\mathrm{m}^{2}$, thus defining the Practiced loading rate.

Carcasses were evaluated from 240 male and 168 female animals transported in straight trucks $(10,60 \times 2,40 \mathrm{~m})$, which had capacities of 20 males or 21 females. Also evaluated were 120 males and 93 females, transported in livestock trailers (14.80 x $2.60 \mathrm{~m}$ ), with capacity of 30 males or 31 females. Additionally, 80 males were evaluated, transported in straight truck with trailer configurations (17.50 x $2.60 \mathrm{~m}$ ) which had a capacity of 40 animals. No transportation of females was observed during the study for this transport configuration.

To characterize the truck body models used for transport, the straight truck was considered a non-articulated vehicle, with two or three cargo compartments, one floor and three axles; the livestock trailer model was considered an articulated vehicle with three loading compartments and three of four axles; and the straight truck with trailer is an articulated vehicle with five or six load compartments and only one floor, usually with five axles. The average animal transport distance was $105 \pm 45 \mathrm{~km}$.

The minimum area occupied per animal in the truck was assessed according to equations of the European Union Farm Animal Welfare Council (FAWC) (FAWC, 1992) and the Animal Welfare Advisory Committee (AWAC) of New Zealand (RANDALL, 1993), in which both establish practices that ensure animal welfare, where:

FAWC: $\mathrm{A}=0.021 \times \mathrm{LW}^{0.67}$

AWAC: $A=0.01 \times \mathrm{LW}^{0.78}$, in which: 
$A=$ Minimum area $\left(\mathrm{m}^{2}\right)$ that must be occupied by the animal; and

$\mathrm{LW}=$ live weight $(\mathrm{kg})$ of the animal.

The data was analyzed in a completely randomized design (CRD) with two sex classes (male and female), three carcass regions (hindquarter, short ribs, forequarter), and in three truck types (straight truck, straight truck with trailer, and livestock trailer) or two when necessary, with the appropriate loading rates. The data was submitted to analysis of variance by PROC GLM at 5\% significance using the $\mathrm{SAS}^{\circledR}$ program (STATISTICAL ANALYSIS SOFTWARE, 2012). When significant differences were detected for the studied variables, they were compared by the student T-test at the same level of significance.

\section{RESULTS AND DISCUSSION}

In the three truck body models it was observed that most carcasses analyzed presented a frequency of 1-5 bruises, with no carcass presenting a total absence of trauma or more than 15 (Table 1).

When relating the bruising frequencies with the area in $\mathrm{m}^{2}$ per animal as practiced in the upper Pantanal region during the realization of this project, if was found that the straight truck with trailer configuration showed the lowest bruising index. Although, there were no cases without bruises among the different truck configurations, a frequency above 11 bruises was not observed in any carcass evaluated during the execution of this project that were transported in this type of vehicle; the same was not true for the straight truck and livestock trailers, which presented carcasses with 11-15 bruises.
When evaluating the minimum areas according to the equations (FAWC and AWAC), there was a very large difference in the areas occupied per $\mathrm{m}^{2}$, which were always smallest $(\mathrm{P}<0.001)$ for the straight truck, whereas, the practiced density was lowest $(\mathrm{P}<0.001)$ in the straight truck with trailer configuration. GRANDIN (2004) recommended an area for animals weighing $545 \mathrm{~kg}$ of $1.35 \mathrm{~m}^{2}$ for cattle, and this value is $10 \%$ higher for animals with horns. According to the same author, for cattle weighing $635 \mathrm{~kg}$ this recommendation can reach up to $1.70 \mathrm{~m}^{2}$ per animal. For animals transported by the straight truck with trailer configuration (similar weight), the calculated area was more accurate according to the AWAC equation; however, it is good to confirm that there are rare studies in literature comparing suitable areas for cattle in different truck model bodies.

Regarding the straight truck with trailer configuration one particularity is observed: the low area in $\mathrm{m}^{2}$ occupied by the animal (1.14) is reflected in the loading rate $\left(477.2 \mathrm{~kg} / \mathrm{m}^{2}\right)$ above the average used in Brazil. According to TARRANT \& GRANDIN (1993), in high density situations the low mobility of animals can cause falls, and even prevent them from getting back up and cause trampling; however, it should be stressed that the same situation can also be verified in low densities. Thus, studies to determine specific equations for Brazil with regards to the capacity of this transport option are essential.

According to MENDONÇA et al. (2019), transportation in vehicles with greater load capacity (number of animals) as in the straight truck with trailer configuration, results in greater injuries. This

Table 1 - Frequency of bruises in male bovine carcasses transported in straight trucks, livestock trailers, and straight truck and trailer configurations and area $\left(\mathrm{m}^{2}\right)$ occupied by each animal according to the average live weight (LW).

\begin{tabular}{|c|c|c|c|c|c|c|c|c|c|}
\hline \multirow[b]{2}{*}{ Truck } & \multicolumn{5}{|c|}{ 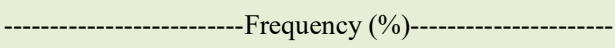 } & \multirow[t]{2}{*}{ LW (kg) } & \multicolumn{3}{|c|}{-Area $\left(\mathrm{m}^{2}\right)----$} \\
\hline & 0 & $1-5$ & $6-10$ & $11-15$ & $>15$ & & PRAT & FAWC & AWAC \\
\hline Str. truck1 & 0 & 75.8 & 22.6 & 1.6 & 0 & 511.4 & $1.27 \mathrm{a}$ & $1.37 \mathrm{c}$ & $1.29 \mathrm{c}$ \\
\hline Liv. trailer2 & 0 & 67.6 & 28.8 & 3.6 & 0 & 618.4 & $1.28 \mathrm{a}$ & $1.56 \mathrm{a}$ & $1.50 \mathrm{a}$ \\
\hline Tru. trailer3 & 0 & 70.9 & 29.1 & 0 & 0 & 544.0 & $1.14 \mathrm{~b}$ & $1.43 b$ & $1.36 \mathrm{~b}$ \\
\hline P Value & & & & & & & $<0.001$ & $<0.001$ & $<0.001$ \\
\hline
\end{tabular}

Different letters in the column indicate difference at the $5 \%$ level by the Student's T-test.

$(\%)$ : Percentage of carcasses affected by bruises at the predetermined frequencies.

LW (kg): Average live weight $(\mathrm{kg})$ of the animals evaluated.

${ }^{1}$ Straight truck; ${ }^{2}$ Livestock trailer; ${ }^{3}$ Straight truck and trailer.

PRAT.: Practiced area (Space occupied by each animal in $\mathrm{m}^{2}$ during transport in the region under study).

FAWC: $A=0.021 \times \mathrm{LW}^{0.67}$.

AWAC: $\mathrm{A}=0.01 \times \mathrm{LW}^{0.78}$. 
argument; therefore, reinforces the hypothesis that transport of cattle in this truck type may present a greater number of animals lying down, mainly due to instability. Additionally, such long vehicles have the greater centrifugal displacement effect caused by the increased length of the vehicle, which would cause greater vibration to animals (GHEZZI et al., 2008). These arguments justify the need for additional studies that focus on the straight truck with trailer configuration to better determine the area per animal and its correlation with the bruising frequency.

For females, all areas $\left(\mathrm{m}^{2}\right)$ differed $(\mathrm{P}<0.001)$ between truck types, where the minimum areas calculated by FAWC and AWAC were numerically smaller than those practiced in the upper Pantanal region where the study was conducted (Table 2). Carcasses with total absence of bruises were observed only for animals transported by the straight truck.

BATISTA DE DEUS et al. (1999) stated that lower loading densities increase space and favor the movement of animals inside the truck, providing greater comfort, but on the other hand in larger spaces the animals get injured by hitting the walls of the transport vehicle or bumping into each other. It should be noted that females transported by straight truck and livestock trailer had a higher carcass bruising index for the 11-15 frequency (5.7 and 12.6\%, respectively) compared to males transported in the same body models. According to VAZ et al. (2012), females tend to have lower bone yield than males, as well as lower fat coverage, resulting in a higher bruise index in function of their muscle mass; however, their lower carcass weight becomes an obstacle to verify the loading rates and ideal areas $\left(\mathrm{m}^{2}\right)$.
GRANDIN (2004) recommended that 360 $\mathrm{kg}$ animals have an available area of 1.00 to $0.95 \mathrm{~m}^{2}$. The livestock trailer fits this requirement, since the average weight of the animals transported was 357.9 $\mathrm{kg}$ and when using the AWAC equation the minimum area determined was $0.98 \mathrm{~m}^{2}$; however, it is important to note that the females transported in this truck presented bruises in all carcasses evaluated. In this sense, it should be noted that the practiced area or the minimum area calculated by the equations would not be viable for light females transported in these vehicles in the Pantanal region of Mato Grosso do Sul.

The animals transported in the different trucks did not differ $(\mathrm{P}>0.05)$ with regards to the percentage of bruises in the hindquarter; however, the straight truck with trailer configuration presented the lowest $(\mathrm{P}=0.0025)$ index of bruises in the forequarter and the greatest $(\mathrm{P}=0.047)$ in the short rib region of animals transported in the upper Pantanal (Table 3).

Animals transported in the straight truck showed the lowest $(\mathrm{P}<0.001)$ loading rates or densities, both in terms of those practiced as observed in this research or recommended by the FAWC and AWAC equations, while the livestock trailers presented the highest densities, independent of the evaluation method. The practiced loading rate and the minimum recommended by the AWAC for straight trucks are within the average values of those utilized in the Brazilian territory according to ROÇA (2001), who reported an average of 390 to $410 \mathrm{~kg} / \mathrm{m}^{2}$. However, this coincided with one of the greatest frequencies of bruises in the forequarter, different from that observed for the straight truck with trailer configuration, which despite the high loading rate practiced, according to the average for Brazil, presented a lower frequency

Table 2 - Frequency of bruises in female bovine carcasses transported in straight trucks, livestock trailers, and straight truck and trailer configurations and area $\left(\mathrm{m}^{2}\right)$ occupied by each animal according to the average live weight (LW).

\begin{tabular}{|c|c|c|c|c|c|c|c|c|c|}
\hline \multirow[b]{2}{*}{ Truck } & \multicolumn{5}{|c|}{ 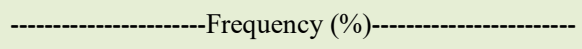 } & \multirow[t]{2}{*}{ LW (kg) } & \multicolumn{3}{|c|}{ 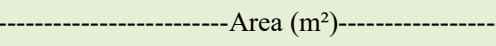 } \\
\hline & 0 & $1-5$ & $6-10$ & $11-15$ & $>15$ & & PRAT & FAWC & AWAC \\
\hline Str. truck ${ }^{1}$ & 3.9 & 80.9 & 9.5 & 5.7 & 0 & 337.4 & $1.21 \mathrm{~b}$ & $1.04 \mathrm{~b}$ & $0.94 b$ \\
\hline Liv. trailer $^{2}$ & 0 & 46.3 & 35.8 & 12.6 & 5.3 & 357.9 & $1.24 \mathrm{a}$ & $1.08 \mathrm{a}$ & $0.98 \mathrm{a}$ \\
\hline P Value & & & & & & & $<0.001$ & $<0.001$ & $<0.001$ \\
\hline
\end{tabular}

Different letters in the column indicate difference at the $5 \%$ level by the Student's T-test.

$(\%)$ : Percentage of carcasses affected by bruises at the predetermined frequencies.

LW $(\mathrm{kg})$ : Average live weight $(\mathrm{kg})$ of the animals evaluated.

${ }^{1}$ Straight truck; ${ }^{2}$ Livestock trailer.

PRAT.: Practiced area (Space occupied by each animal in $\mathrm{m}^{2}$ during transport in the region under study).

FAWC: $\mathrm{A}=0.021 \times \mathrm{LW}^{0.67}$.

AWAC: $A=0.01 \times \mathrm{LW}^{0.78}$. 
Table 3 - Incidence of bruises by region in male carcasses transported in straight trucks, livestock trailers, and straight truck and trailer configurations, and their respective loading rates.

\begin{tabular}{|c|c|c|c|c|c|c|c|}
\hline \multirow[b]{2}{*}{ Truck } & \multirow[t]{2}{*}{ LW (kg) } & \multicolumn{3}{|c|}{ 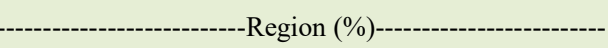 } & \multicolumn{3}{|c|}{ 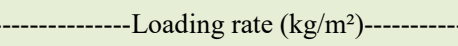 } \\
\hline & & Hindquarter & Forequarter & Short rib & PRAT $^{*}$ & FAWC & AWAC \\
\hline Str. truck ${ }^{1}$ & 511.4 & 60.3 & $32.6 \mathrm{a}$ & $7.2 \mathrm{c}$ & $402.8 b$ & $373.3 \mathrm{c}$ & $396.3 b$ \\
\hline Liv. trailer ${ }^{2}$ & 618.4 & 58.5 & $33.9 \mathrm{a}$ & $7.6 \mathrm{~b}$ & $483.1 \mathrm{a}$ & $396.4 \mathrm{a}$ & $412.3 \mathrm{a}$ \\
\hline Tru. trailer $^{3}$ & 544.0 & 54.4 & $15.1 \mathrm{~b}$ & $30.5 \mathrm{a}$ & $477.2 \mathrm{a}$ & $380.4 b$ & $400.0 \mathrm{~b}$ \\
\hline$P$ value & & 0.3431 & 0.0025 & 0.047 & $<0.001$ & $<0.001$ & $<0.001$ \\
\hline
\end{tabular}

Different letters in the column indicate difference at the 5\% level by the Student's T-test.

LW (kg): Average live weight $(\mathrm{kg})$ of the animals evaluated.

${ }^{1}$ Straight truck; ${ }^{2}$ Livestock trailer; ${ }^{3}$ Straight truck and trailer.

Region (\%): Percent of bruises observed in the hindquarter, forequarter and short rib regions.

$\mathrm{Kg} / \mathrm{m}^{2}$ PRAT: Loading in $\mathrm{kg} / \mathrm{m}^{2}$ Practiced in the region under study while conducting the experiment.

$\mathrm{Kg} / \mathrm{m}^{2}$ FAWC: Minimum loading in $\mathrm{kg} / \mathrm{m}^{2}$ according to the FAWC equation.

$\mathrm{Kg} / \mathrm{m}^{2}$ AWAC: Minimum loading in $\mathrm{kg} / \mathrm{m}^{2}$ according to the AWAC equation.

*Average loading rate for Brazil according to ROÇA (2001) (390 to $\left.410 \mathrm{~kg} / \mathrm{m}^{2}\right)$.

of bruises in that same region, but the short rib region was that most affected.

The high bruising rates in the hindquarter do not seem to be associated with the loading rate being greater than $390-410 \mathrm{~kg} / \mathrm{m}^{2}$, the average reported by ROÇA (2001), since the frequencies did not statistically differ but the densities in the livestock trailer and straight truck with trailer configurations were higher than the averages reported by the same author and that found for the straight truck. According to CIVEIRA et al. (2006), the high rate of bruises in this region, in a high capacity situation, can be attributed to the anatomy of the bovine itself, due to the presence of the ischial tuberosity structure favoring the appearance of trauma resulting from shocks, which may justify the data from the livestock trailer and the straight truck with trailer configurations. Furthermore, HOFFMAN \& LÜHL (2012) reported that animals are more susceptible to injuries when transported in larger trucks; however, the authors were unable to establish whether this higher incidence was the result of the truck drive shaft or due to the animal density within the vehicle.

In relation to the forequarter, males transported in the straight truck and livestock trailer had the highest bruise rates; however, the minimum loading rates according to the AWAC and FAWC were similar to the averages reported in Brazil (ROÇA, 2001). This index was higher than that observed by MOREIRA et al. (2014), who when evaluating the occurrence of bruises in bovine carcasses transported over two distances, observed $17.5 \%$ bruises for the same region in males. The lowest index was observed for males transported in the straight truck and trailer, correlating precisely with the lowest minimum capacity calculated by the AWAC equation. However, it also correlated with the highest transport density Practiced during this project, for this type of vehicle, depending on the form of loading evaluation, the density recommendation may differ.

Males transported in the straight truck with trailer configuration had the highest rate of bruising for in the short rib region, being transported at actual loading rates above the national average (ROÇA, 2001), but not higher than in the livestock trailer. These indices were higher than those observed by BRAGGION \& SILVA (2004), who reported 12.16\% for the same region in males slaughtered in the Pantanal region of Mato Grosso do Sul. In this study it was reported that the structure of the straight truck with trailer configuration resulted in a number of falls that had a direct influence on the higher proportion of bruises in the short rib region; therefore, the bruises may be related to the way the animal suffers a fall in this type of transport, projecting the thoracic region which makes it prone to bruising.

Regarding the females, animals transported in the livestock trailer presented a higher $(\mathrm{P}<0.001)$ rate of bruises in the forequarter, with no difference between the other regions (Table 4). These results differ from those reported by CIVEIRA et al. (2006), who found the prevalence of more severe bruises in the hindquarter region for females, but this author did not consider the truck model used. 
Table 4 - Incidence of bruises by region in female carcasses transported in straight trucks, and livestock trailers configurations, and their respective loading rates.

\begin{tabular}{|c|c|c|c|c|c|c|c|}
\hline \multirow[b]{2}{*}{ Truck } & \multirow[t]{2}{*}{ LW (kg) } & \multicolumn{3}{|c|}{ 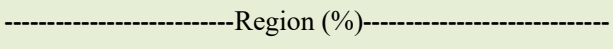 } & \multicolumn{3}{|c|}{---------Loading rate $\left(\mathrm{kg} / \mathrm{m}^{2}\right)$--------. } \\
\hline & & Hindquarter & Forequarter & Short rib & PRAT $^{*}$ & FAWC & AWAC \\
\hline Str. truck ${ }^{1}$ & 377.9 & 72.4 & $12.2 \mathrm{~b}$ & 15.4 & $278.8 b$ & $324.4 b$ & $358.9 \mathrm{~b}$ \\
\hline Liv. trailer $^{2}$ & 451.0 & 42.7 & $51.7 \mathrm{a}$ & 5.6 & $288.6 \mathrm{a}$ & $331.4 \mathrm{a}$ & $365.2 \mathrm{a}$ \\
\hline$P$ value & & 0.068 & $<0.001$ & 0.623 & $<0.001$ & $<0.001$ & $<0.001$ \\
\hline
\end{tabular}

Different letters in the column indicate difference at the 5\% level by the Student's T-test.

LW (kg): Average live weight $(\mathrm{kg})$ of the animals evaluated.

${ }^{1}$ Straight truck; ${ }^{2}$ Livestock trailer.

Region (\%): Percent of bruises observed in the hindquarter, forequarter and short rib regions.

$\mathrm{Kg} / \mathrm{m}^{2}$ PRAT: Loading in $\mathrm{kg} / \mathrm{m}^{2}$ practiced in the region under study while conducting the experiment.

$\mathrm{Kg} / \mathrm{m}^{2} \mathrm{FAWC}$ : Minimum loading in $\mathrm{kg} / \mathrm{m}^{2}$ according to the $\mathrm{FAWC}$ equation.

$\mathrm{Kg} / \mathrm{m}^{2}$ AWAC: Minimum loading in $\mathrm{kg} / \mathrm{m}^{2}$ according to the AWAC equation.

*Average loading rate for Brazil according to ROÇA (2001) (390 to $\left.410 \mathrm{~kg} / \mathrm{m}^{2}\right)$.

When considering transportation with loading rates below the average used in the Brazilian territory for females, regardless of the truck body model,; although, the values are always higher in the livestock trailer, the Practiced rates in the region or the minimum rates calculated by FAWC and AWAC provided more space for the animals and this possibility of movement contributed to an increase in the rate of bruises due to shocks between the animals themselves and against the truck body. As observed by TARRANT et al. (1993), lower loading densities can generate a great lack of support and balance inside the vehicle, forcing the animals to support themselves on the sides; this movement in the present study possibly caused more trauma in animals transported in the livestock trailer, significantly affecting the forequarter region of females.

Regarding the short rib region; although, the percentage of bruises is not significant $(\mathrm{P}>0.05)$, the value reported for the straight truck body is similar to that observed by BRAGGION \& SILVA (2004), in which the rate was $18.09 \%$ bruises in the same region, also for females.

\section{CONCLUSION}

It can be affirmed that for males there was a relationship between the high bruising rates and the loading rate practiced during transportation, especially for the livestock trailer and straight truck with trailer configurations, while the females were influenced by low densities, regardless of the truck model used for transportation in the upper Pantanal of Mato Grosso do Sul, Brazil. Use of the FAWC and AWAC equations to determine the capacity under national conditions should be better studied. In general, estimates of the AWAC are closer to the Practiced densities observed during this study.

\section{BIOETHICS AND BIOSSECURITY COMMITTEE APPROVAL}

The Ethics Committee on the Use of Animals (Comissão de Ética no Uso de Animais - CEUA) of the UEMS certified the use of animals in accordance with protocol No. 023/2017.

\section{ACKNOWLEDGEMENTS}

The research was financed in part by the Coordenação de Aperfeiçoamento de Pessoal de Nível Superior (CAPES), Brazil, Finance code 001 and Fundação de Apoio ao Desenvolvimento do Ensino, Ciência e Tecnologia do Estado de Mato Grosso do Sul, MS, Brazil (FUNDECT).

\section{DECLARATION OF CONFLICT OF INTERESTS}

The authors declare no conflict of interest. The founding sponsors had no role in the design of the study; in the collection, analyses, or interpretation of data; in the writing of the manuscript, and in the decision to publish the results.

\section{AUTHORS' CONTRIBUTIONS}

All authors contributed equally to the design and writing of the manuscript. All authors critically reviewed the manuscript and approved the final version. 


\section{REFERENCES}

ADZITEY, F. Effect of pre-slaughter animal handling on carcass and meat quality. International Food Research Journal, v.18, p.256-263, 2011. Available from: <http://www.ifrj.upm edu.my/18\%20(02)\%202011/(3)\%20IFRJ-2010-140.pdf>. Accessed: Mar. 05, 2019.

ANDRADE, E. N. et al. Manejo pré-abate de bovinos de corte no Pantanal, Brasil. Archivos de Zootecnia, v.58, p.301304, 2009. Available from: <http://scielo.isciii.es/scielo. php ?script $=$ sci_arttext\&pid $=$ S0004-05922009000200018>. Accessed: Jan. 10, 2020.

ASSIS, D. A. et al. Direct losses due abscesses and bruised in beef carcasses. Revista Portuguesa de Ciências Veterinárias Lisboa, v.106, n.577-580, p.47-51, 2011. Available from: $<$ http://www.fmv.ulisboa.pt/spcv/PDF/pdf12_2011/47-51.pdf $>$. Accessed: Oct. 21, 2018.

BATISTA DE DEUS, J. C. et al. Efeito da distância de transporte de bovinos no metabolismo post mortem. Revista Brasileira de Agrociência, v.5, p.152-156, 1999. Available from: <https://periodicos.ufpel.edu.br/ojs2/index.php/CAST/ article/view/264/260>. Accessed: Oct. 13, 2018.

BRAGGION, M.; SILVA, R. A. Quantificação de Lesões em Carcaças de Bovinos Abatidos em Frigoríficos no Pantanal Sul- Mato-Grossense. Comunicado técnico, v.45, p.1-4, 2004. Available from: $<$ https://ainfo.cnptia.embrapa.br/digital/bitstream/ item/79539/1/COT45.pdf $>$. Accessed: Oct. 15, 2018.

CIVEIRA, M. P. et al. Avaliação do bem-estar animal em bovinos abatidos para consumo em frigorífico do Rio Grande do Sul. Veterinária em Foco, v.4, p.5-11, 2006. Available from: $<$ https://www.bvs-vet.org.br/vetindex/periodicos/veterinariaem-foco/>. Accessed: Oct, 13, 2018.

DINIZ, P. P. et al. Efeitos do transporte no bem-estar e qualidade da carne de bovinos. Revista Brasileira de Engenharia de Biossistemas, v.5, p.137-141, 2011. Available from: <http:// seer.tupa.unesp.br/index.php/BIOENG/article/view/122/121>. Accessed: Aug. 12, 2019.

FAWC (Farm Animal Welfare Council). FAWC updates the five freedom. Veterinary Record, 1992. 357p.

GHEZZI, M. D. et al. Evaluacion de las practicas relacionadas con el transporte terrestre de hacienda que causan perjuicios economicos en la cadena de ganados y carnes. Sítio Argentino de Produção Animal, n.5, p.1-19, 2008. Available from: < http:// www.ipcva.com.ar/files/ct5.pdf >. Accessed: Aug. 12, 2019.

GRANDIN T. El transporte del ganado: guía para las plantas de faena. Available from: <https://www.grandin.com/spanish/ transporte.genado.html>. 2004. Accessed: Aug. 12, 2019.

GONZÁLEZ, L.A. et al. Space allowance during commercial long distance transport of cattle in North America. Journal of Animal Science, v.90, p.3618-3629. 2012. Available from: <https://academic.oup.com/jas/articleabstract/90/10/3618/4717901>. Accessed: Aug. 13, 2019. doi: $10.2527 /$ jas.2011-4771

HOFFMAN, D. E. et al. Effect of source of cattle and distance transported to a commercial slaughter facility on carcass bruises in mature beef cows. Journal of the American Veterinary Medical Association, v.212, p.668-672, 1998. Available from: $<$ https://europepmc.org/abstract/med/9524638>. Accessed: Oct. 12,2018

HOFFMAN, L. C.; LÜHL, J. Causes of cattle bruising during handling and transport in Namibia. Meat Science, v.92, p.115124, 2012. Available from: <https://www.sciencedirect.com/ science/article/pii/S0309174012001428>. Accessed: Mar. 05, 2019. doi: 10.1016/j.meatsci.2012.04.021.

MENDONÇA, F. S. et al. Pre-slaughtering factors related to bruises on cattle carcasses. Animal Production Science, v.58, p.385-392, 2018. Available from: <https://www.publish.csiro. au/AN/AN16177>. Accessed: Mar. 05, 2019. doi: 10.1071/ AN16177.

MOREIRA, P. S. A. et al. Ocorrência de hematomas em carcaças de bovinos transportados por duas distâncias. Revista Brasileira de Saúde e Produção Animal, v.15, p.689-695, 2014. Available from: <http://www.scielo.br/scielo.php?pid=S1519$99402014000300018 \&$ script $=$ sci abstract $\&$ tlng $=$ pt $>$. Accessed Nov. 05, 2018. doi: 10.1590/S1519-99402014000300018.

NUNES, C. L. C. et al. Ocorrência de hematomas e lesões em carcaças bovinas e sua relação com o transporte rodoviário Boletim de Indústria Animal, v.75, p.1-7, 2018. Available from: $<$ http://www.iz.sp.gov.br/bia/index.php/bia/article/view/1487>. Accessed: Mar. 20, 2019. doi: 10.17523/bia.2018.v75.e1434.

RANDALL, J. M. Environmental parameters necessary to define comfort for pigs, cattle and sheep in livestock transporters. Animal Science, v.57, p.299-307, 1993. Available from: $\quad<$ https://www.cambridge.org/core/journals/animalscience/article/environmental-parameters-necessary-to-definecomfort-for-pigs-cattle-and-sheep-in-livestock-transporters/ A0BEBAFBB988AE5346D228EBF8680E58>. Accessed: Jan. 10, 2020. doi: 10.1017/S0003356100006929.

ROÇA, R. O. Humanes laughter of cattte. Revista de Educação Continuada em Medicina Veterinária e Zootecnia do CRMV-SP, v.4, p.73-85, 2001. Available from: <https:// www.revistamvez-crmvsp.com.br/index.php/recmvz/article/ view/3322/2527>. Accessed: Oct. 30, 2018.

ROMERO, M. H. et al. Risk factors influencing bruising and high muscle $\mathrm{pH}$ in Colombian cattle carcasses due to transport and pre-slaughter operations. Meat Science, v.95, p.256-263, 2013. Available from: $<$ https://www.sciencedirect.com/science/ article/pii/S0309174013002088>. Accessed: Oct. 01, 2018. doi: 10.1016/j.meatsci.2013.05.014.

STATISTICAL ANALYSIS SYSTEM INSTITUTE. SAS user's guide: statistics. Version 9.2. Cary, 2012. 373p.

TARRANT, P. V. et al. Long distance transportation of steers to slaughter: effect of stocking density on physiology, behaviour and carcass quality. Livestock Production Science, v.30, p.223-238, 1992. Available from: <https://www.sciencedirect. com/science/article/pii/S0301622606800126>. Accessed: Oct. 27, 2018. doi: 10.1016/S0301-6226(06)80012-6.

TARRANT, P. V. et al. The effect of stocking density during 4-hour transport to slaughter on behaviour, blood constituents and carcass bruising in Friesian steers. Meat Science, v.24, p.209-222, 1988. Available from: <https://www.sciencedirect. 
com/science/article/pii/0309174088900794>. Accessed: Oct. 28, 2018. doi: 10.1016/0309-1740(88)90079-4.

TARRANT, P. V.; GRANDIN, T. Cattle transport. Livestock handling and transport. 1. ed. CAB International, 1993. p.109-126.

VAZ, F. N. et al. Análise econômica, rendimentos de carcaça e dos cortes comerciais de /vacas de descarte $5 / 8$ hereford $3 / 8$ nelore abatidas em diferentes graus de acabamento. Ciência Animal
Brasileira, v.13, p.338-345, 2012. Available from: <https://www. revistas.ufg.br/vet/article/view/17572>. Accessed: Oct. 28, 2018. doi: 10.5216/cab.v13i3.17572.

WARRISS, P. D. The handling of cattle pre-slaughter and its effects on carcass and meat quality. Applied Animal Behaviour Science, v.28: p.171-186. 1990. Available from: <https://www.sciencedirect.com/science/article/abs/ pii/016815919090052F $>$. Accessed: Jan. 13, 2020. doi: 10.1016/0168-1591(90)90052-F. 